\title{
Ecological Structure and Fruit Production of African Fan Palm (Borassus aethiopum) Populations
}

\author{
Christine Ouinsavi, Charlemagne Gbémavo, Nestor Sokpon
}

Laboratoire d'Etudes et de Recherches Forestières (LERF), Faculté d'Agronomie, Université de Parakou, Parakou, Benin. Email: \{ouinsch, cgbemavo,nsokpon\}@yahoo.fr

Received July $6^{\text {th }}, 2011$; revised August $22^{\text {nd }}, 2011$; accepted September $9^{\text {th }}, 2011$.

\begin{abstract}
Ecological structure and fruit production of African fan palm stands in Benin were studied on the basis of surveys laid out in ten (10) populations located in three ecological zones. Dendrometric and fruit production parameters such as: diameter at breast height (dbh), total height (TH), number of fruit bunch per tree, number of fruits per tree, number of seeds per fruit, fruit length and width were measured on all African fan palm trees within thirteen (13) plots of 1,000 $\mathrm{m}^{2}$. Diameter and height classes distribution of the palms in each ecological zone adjusted to Weibull distribution showed a bell shaped curve with left dissymmetry, characteristic of young stands (form coefficient between 1 and 3.6). African fan palm stem number was 156 trees/ha. Variation of dbh, TH, number of fruit bunch per tree were highly significant between populations and ecological zones $(P<0.05 \%)$. Trees from Sudanian zone were highly grown (mean $d b h=$ $52.2 \mathrm{~cm}$ ) while those of Sudano - Guinean transition zone were less (mean $\mathrm{dbh}=32.73 \mathrm{~cm}$ ) and dominated by female trees. African fan palm stands of Pahou is suitable for seed collection for in situ conservation of the species while those of Ouorghi and Akomiah could provide fruits for edible hypocotyls production.
\end{abstract}

Keywords: Ecological Structure, African Fan Palm, Fruit Production, Population

\section{Introduction}

Tropical forests are an important reservoir of biodiversity and they play a fundamental role in giving satisfaction to many needs of the people. Nowadays, the non timber forest products, exploited and consumed by local people are becoming very scarce due to high human pressure, over exploitation, non sufficient silvicultural data, climate changes highlighted by the recurrent dry seasons, all situation that compromises local people food security and income. It is the case of African fan palm (Borassus aethiopum) which provide people with a wide usefulness on ecological, nutritional, therapeutically, small scale producing and culturally plans [1-5]. African fan palm roots are used as anti asthmatic. Its leaves are used in many craftsmen products. The petioles are used as fencing, firewood and the hypocotyls are edible [4]. The male flowers are used as soils fertilizers and as fodder [6]. They are considered as an excellent fodder and their nutrients content are similar to those of ground nut and cowpea haulm [7]. The bole of the palm is used in carpentry for house and bridge building. Its wood is very resis- tant to termites and fungi attacks and to climate variations.

In Benin, a research work carried out by [3] and [4] revealed that from the sampled population, $90 \%$ of the households eats African fan palm hypocotyls, $16 \%$ eats the fruits and $13 \%$ consume the almonds. The same authors showed that African fan palm contributes to cure 33 diseases and is of great importance to Lokpa and Yom ethnic groups in the Northern Benin. African fan palm products are sold and can allow the traders to draw monthly gross margin ranging from 20,920 to 112,975 FCFA for hypocotyls, 332 to 1925 FCFA for fans selling, average of 6500 FCFA for hats and 1616 to 3264 FCFA for sieves selling. According to [3], more than $88 \%$ of the organs of African fan palm are useful (hypocotyls, fruits, almonds, leaves, petioles, blades, boles) and harvested from natural forests. Meanwhile, African fan palm can generate a lot income to the rural population and contribute to poverty alleviation only few works were carried out on the structure and dynamics of its populations.

This paper aims to assess ecological structure and pa- 
ttern of fruit production of Borassus aethiopum for a better management of the tree populations in Benin.

\section{Material and methods}

\subsection{The Study Area}

This study was carried out in the Republic of Benin located in West Africa between $1^{\circ}$ and $3^{\circ} 40^{\prime} \mathrm{E}$ and $06^{\circ} 30^{\prime}$ and $12^{\circ} 30^{\prime} \mathrm{N}$. It is bordered by Niger in the north, Burkina Faso in the northwest, Togo in the west, Nigeria in the east and the Atlantic Ocean in the south and covers an area of 112,622 $\mathrm{km}^{2}$ (Figure 1).

Benin is located in the Dahomey gap which is characterized by numerous physical constraints. The mean annual rainfall is low (900 - $1300 \mathrm{~mm}$ ) compared with neighbouring countries in the Guineo-Congolean zone such as Ghana and Côte d'Ivoire (average of $1500 \mathrm{~mm}$ ) and Cameroon (1800 - $3000 \mathrm{~mm})$.

Reference [8] distinguished four major types of vegetation in Benin which are described as follows:

The coastal and sub-coastal zone, which extends from the coast $\left(6^{\circ} 20^{\prime} \mathrm{N}\right.$ up to $\left.7^{\circ} \mathrm{N}\right)$, is composed of beach vegetation with an abundance of Remirea maritima and Ipomea pescaprae, anthropic vegetation of mangrove swamp forests characterized by Rhizophora racemosa, Avicennia germinans and Dalbergia ecastaphylum, riparian forests, oil palm and coconut plantations. This zone has a subequatorial climate type with two rainy seasons (from mid-March to mid-July and from mid-September to mid-November) which alternate with two dry seasons (from mid-July to mid-September and from mid-November to mid-March).

The Guineo-Congolean zone composed of relict semideciduous forests characterized by species such as: Dialium guineense, Triplochiton scleroxylon, Strombosia glaucescens, Cleistopholis patens, Ficus mucuso, Cola cordifolia, Ceiba pentandra, Trilepisium madagascariense, Celtis spp, Albizia spp, Antiaris toxicaria, Diopyros mespiliformis, Drypetes floribunda, Memecylon afzelii, Celtis brownii, Mimusops andogensis, Daniellia oliveri, Parkia spp and Vitellaria paradoxa [9-11], some savanna and plantation areas.

The Guineo-Sudanian Transition zone with a mosaic of forest woodlands, sometimes dry forests and wooded savanna crossed by gallery forests. The most abundant species found in this zone are: Isoberlinia doka, I. tomentosa, Monotes kerstingii, Uapaca togoensis, Anogeissus leiocarpa, Antiaris toxicaria, Ceiba pentandra, Blighia sapida, Dialium guineense, Combretum fragrans, Entada Africana, Maranthes polyandra, Pterocarpus erinaceus, Terminalia laxiflora and Detarium microcarpum.

These two zones are characterized by a Guinean climate type with two rainy seasons and two dry seasons distributed as above but the short rainy season of this region is sometimes absent. The total annual rainfall reaches $1100 \mathrm{~mm}$.

The Sudanian zone composed of dry forests, savanna woodlands, shrub savanna and savanna grassland. The gallery forests are characterized by species such as: Haematostaphis barteri, Lannea spp, Khaya senegalensis, Anogeissus leiocarpa, Tamarindus indica, Capparis spinosa, Ziziphus mucronata, Combretum spp and Cissus quadrangularis. This zone has a Sudanian climate type with one rainy season (from April to October) followed by one dry season (from November to March). The average rainfall varies from $1100 \mathrm{~mm}$ in the southern part of this zone to $900 \mathrm{~mm}$ in the northern part.

According to the FAO world classification of soils, the major types of soil distinguished in Benin are: Leptosols in the coastal zone, Acrisols, Ferralsols or Lixisols and Vertisols in the Guineo-Congolean zone, Luvisols, Lixisols, Alisols, Plinthosols and Arenosols in the Sudano-Guinean transition and the Sudanian zones. Human pressure on land for agricultural purposes and forest exploitation is considerable. In southern Benin where population density varies from 200 to 450 inhabitants $/ \mathrm{km}^{2}$, average farmland area is 0.5 ha and the fallow system is more or less absent. In the north, where mean population density is 14 inhabitants per $\mathrm{km}^{2}$, average farmland area is 5 ha and fallow length is about 5 years.

Forest over-exploitation has led to declines in the number of some trees species per hectare. Species such as $\mathrm{Mi}$ licia excelsa, Khaya senegalensis, Afzelia Africana and Pterocarpus erinaceus have become scarce in their natural habitat [12]. Human pressure on forest ecosystems has also reduced the occurrence of relict forests, mainly sacred groves [13] and individual trees of some species, such as Milicia excelsa, Triplochiton scleroxylon, Borassus aethiopum, protected by traditional ethno botanic conservation practices [14].

\subsection{B. aethiopum Description and Populations Sampling}

Borassus aethiopum is a common palm in West African humid savannas. It is found in drier areas but is then restricted to riversides [15]. It is a savannah tree of 20 to $30 \mathrm{~m}$ high and 0.30 to $0 .-0 \mathrm{~m}$ of diameter. It is a dioecious, tall, solitary and pleonanthic palm of the Borasseae tribe [16]. Male and female flowers appear on separate trees. Leaves are fan-shaped, induplicate and costapalmate with petioles of 1.5 to $3 \mathrm{~m}$ long. The stem is massive and covered with leaf bases abscising clearly in older individuals. The male flowers are abundant and small, inserted at the base of a bract. The female flowers are larger than the males. Female bear $50-100,1.0-1.5$ 


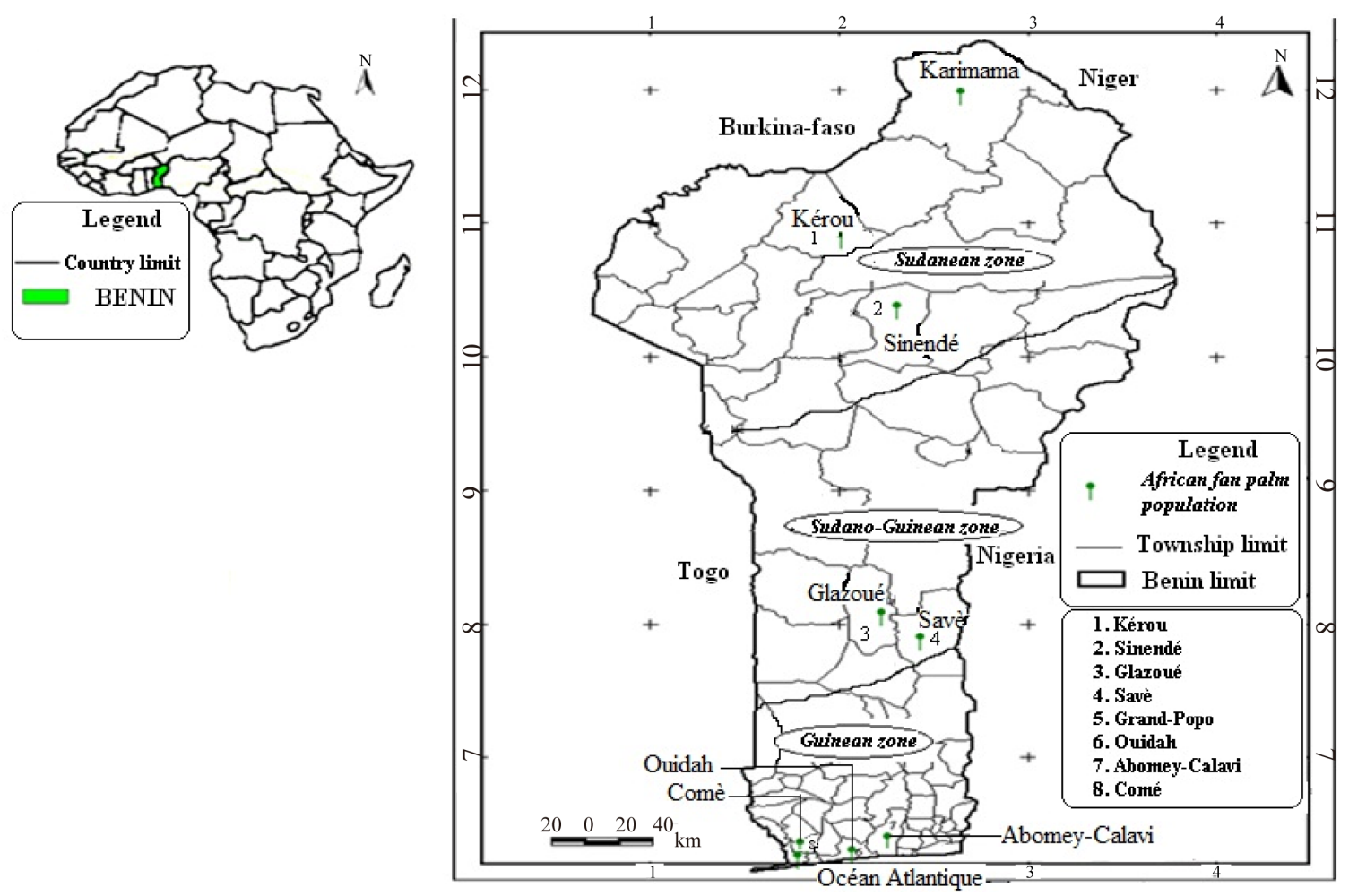

Figure 1. Distribution of African fan palm populations according to the ecological zones of [17].

$\mathrm{kg}$ fresh weight fleshy fruits [15]. Fruits are globulous or ovoid, yellowish when mature with one to four seeds. The sap is used to make palm wine [18]. Stems and leaves are used to construct houses. The tree's roots are used in medicine and the bowl is used in bridge construction and carpentry. Fruits and young seedlings are edible [19]. Seed germination is remote-tubular [16]; [20]: the cotyledonary axis extends downward into the soil and carries the seedling to a depth of $40 \mathrm{~cm}$, where the first roots and leaves develop.

African fan palm is originated from Sahelian Africa and its distribution area ranges from Senegal to Tchad. The species is found in Benin, Niger, Togo, Ghana, Côte d'Ivoire, Gambia, Senegal, Burkina-Faso, Mali, Mauritania, Nigeria and Tchad.

In Benin, African fan palm populations were sampled according to three ecological zones as follows: Goroubi, Loumbou-loumbou, Niaro and Kongourou in the Sudanian zone; Akomiah and Ouorghi in the Sudano-Guinean Transition zone; Se, Grand-Popo, Pahou and Ouidah in the Guinean zone (Table 1).

\subsection{Data Collection}

Rectangular plots of $1000 \mathrm{~m}^{2}$ were laid in each sampled population of African fan palm. The plot number varies according to the area covered by African fan palm population. Diameter at breast high and the total height of all the fan palm trees contained in each plot were measured. In total, 203 palm trees covering $13,000 \mathrm{~m}^{2}$ were measured (Table 2).

The sex of each tree, the number of fruits bunch and the number of fruits per female tree were recorded. The size (length and width) of each fruit and the number of seeds per fruit were also recorded. In total 82 males and 121 female trees were sampled to estimate tree fruit production.

\subsection{Data Analysis}

African fan palm trees distribution within population and according to the ecological zones was adjusted to the Weibull function, commonly nowadays used in Forestry surveys [21-23]. The Weibull distribution is as follows:

$$
f(x)=\frac{c}{b}\left(\frac{x-a}{b}\right)^{c-1} \exp \left[-\left(\frac{x-a}{b}\right)^{c}\right]
$$

$a=$ position parameter; $a=20 \mathrm{~cm}$ (diameter); $a=5$ or $7 \mathrm{~m}$ (Height according to the sites);

$b=$ scale parameter or size parameter;

$c=$ form parameter linked with the observed structure.

Trees diameter or trees height distribution were adjusted to Weibull function with Minitab 14 Software. A one way Analysis of Variance was performed to test for statistical difference between different ecological zones 
Table 1. Distribution of $B$. aethiopum populations according to the three ecological zones.

\begin{tabular}{|c|c|c|c|c|}
\hline Ecological zones & B. aethiopum populations & Latitude & Longitude & Rainfall gradient \\
\hline \multirow{4}{*}{ Sudanian } & Goroubi & $11^{\circ} 55.055$ & $003^{\circ} 15.484$ & \multirow{4}{*}{700 to $900 \mathrm{~mm}$} \\
\hline & Lombou-loumbou & $12^{\circ} 14.217$ & $002^{\circ} 54.218$ & \\
\hline & Niaro & $10^{\circ} 23.433$ & $002^{\circ} 25.039$ & \\
\hline & Kongourou & $10^{\circ} 22.571$ & $002^{\circ} 50.308$ & \\
\hline \multirow{2}{*}{$\begin{array}{l}\text { Sudano-Guinean } \\
\text { Transition }\end{array}$} & Akomiah & $08^{\circ} 06.241$ & $002^{\circ} 32.432$ & \multirow{2}{*}{1000 to $1200 \mathrm{~mm}$} \\
\hline & Ouorghi & $08^{\circ} 10.201$ & $002^{\circ} 37.221$ & \\
\hline \multirow{4}{*}{ Guinean } & $\mathrm{Se}$ & $06^{\circ} 29.037$ & $001^{\circ} 50.152$ & $1100 \mathrm{~mm}$ \\
\hline & Pahou & $06^{\circ} 23.177$ & $002^{\circ} 14.069$ & $1200 \mathrm{~mm}$ \\
\hline & Grand Popo & $06^{\circ} 17.484$ & $001^{\circ} 49.278$ & $900 \mathrm{~mm}$ \\
\hline & Ouidah & $06^{\circ} 23.429$ & $001^{\circ} 58.538$ & $1200 \mathrm{~mm}$ \\
\hline
\end{tabular}

Table 2. Description of B. aethiopum studied populations.

\begin{tabular}{|c|c|c|c|c|c|}
\hline Ecological zones & B. aethiopum populations & Plot number & Trees number & $\begin{array}{l}\text { Total plots number per } \\
\text { ecological zones }\end{array}$ & $\begin{array}{l}\text { Total trees number per } \\
\text { ecological zones }\end{array}$ \\
\hline \multirow{4}{*}{ Sudanian } & Goroubi & 1 & 3 & \multirow{4}{*}{4} & \multirow{4}{*}{62} \\
\hline & Lombou -loumbou & 1 & 21 & & \\
\hline & Niaro & 1 & 21 & & \\
\hline & Kongourou & 1 & 17 & & \\
\hline \multirow{2}{*}{$\begin{array}{l}\text { Sudano-Guinean } \\
\text { Transition }\end{array}$} & Akomiah & 2 & 30 & \multirow{2}{*}{4} & \multirow{2}{*}{60} \\
\hline & Ouorghi & 2 & 30 & & \\
\hline \multirow{5}{*}{ Guinean } & $\mathrm{Se}$ & 1 & 20 & \multirow{4}{*}{5} & \multirow{4}{*}{81} \\
\hline & Pahou & 1 & 18 & & \\
\hline & Grand Popo & 2 & 22 & & \\
\hline & Ouidah & 1 & 21 & & \\
\hline & Total & 13 & 203 & 13 & 203 \\
\hline
\end{tabular}

for variable such as: dbh, total height, fruits number per tree, fruits cluster number per tree, seeds number per fruit, fruit size (length and width) using SPSS for Windows V. 16 Software. Turkey Homogeneity test allows us to separate the site and ecological homogeneous groups. The correlations between growth parameters and fruits production were performed with Minitab 14 Software.

\section{Results}

\subsection{Diameter Classes’ Distribution of B. aethiopum Trees}

Figure 2 showed the class distribution of the fan palm trees diameter according to the different ecological zones. The Weibull distribution of fan palm trees per diameter classes shows a left dissymmetric bell shaped curve with a $\mathrm{c}$ form coefficient comprised between 1 and 3.6 for the three ecological zones. This value of $c$ means that the stands were dominated by young trees. In the Sudanian zone, trees of diameter class centre 35 and 65 were dominant in the stand while in the Sudano-Guinean Tran- sition zone and Guinean zone, trees of diameter class centre 25 were dominant.

\subsection{Total Height Classes Distribution of B. aethiopum Trees}

Figure 3 showed the total height class distribution of trees of African fan palm according to the three ecological zones. This distribution well adjusted to the Weibull function showed a bell shaped curve with a left dissymmetry $(1 \leq c \leq 3.6)$. Like the diameter class distribution, the stands were dominated by young trees. In the Sudanian zone, trees of class $(8-12 \mathrm{~m}$ ) were dominant in the population while in the Sudano-Guinean Transition zone and the Guinean zone, trees of height class (12 - 14 $\mathrm{m})$ were dominant in the stands.

\subsection{Structural Characteristics of B. aethiopum Populations}

Table 3 showed the number of tree per stand and per ecological zones of the studied African Fan Palm popu- 

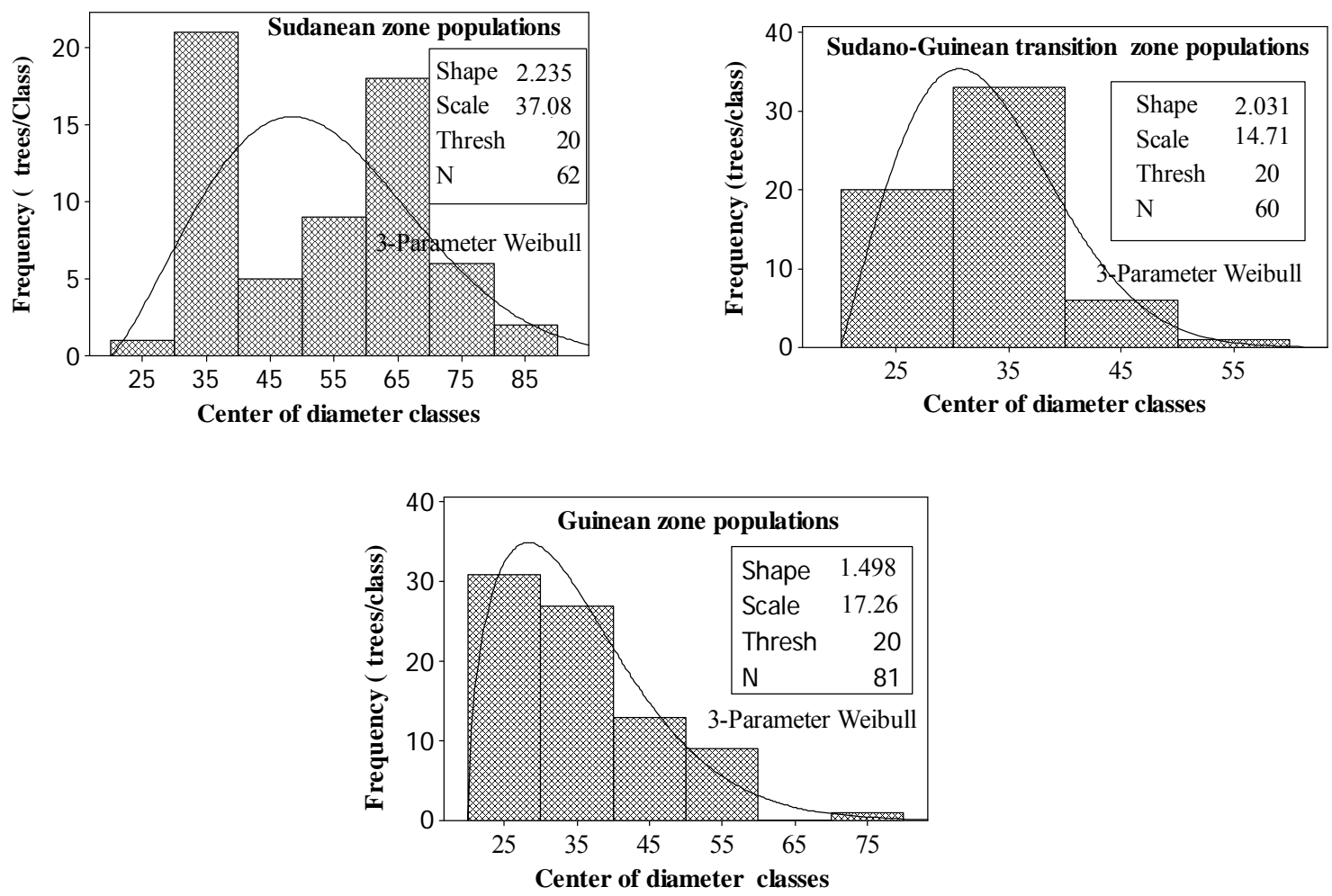

Figure 2. Diameter classes’ distribution of trees of African fan palm populations.
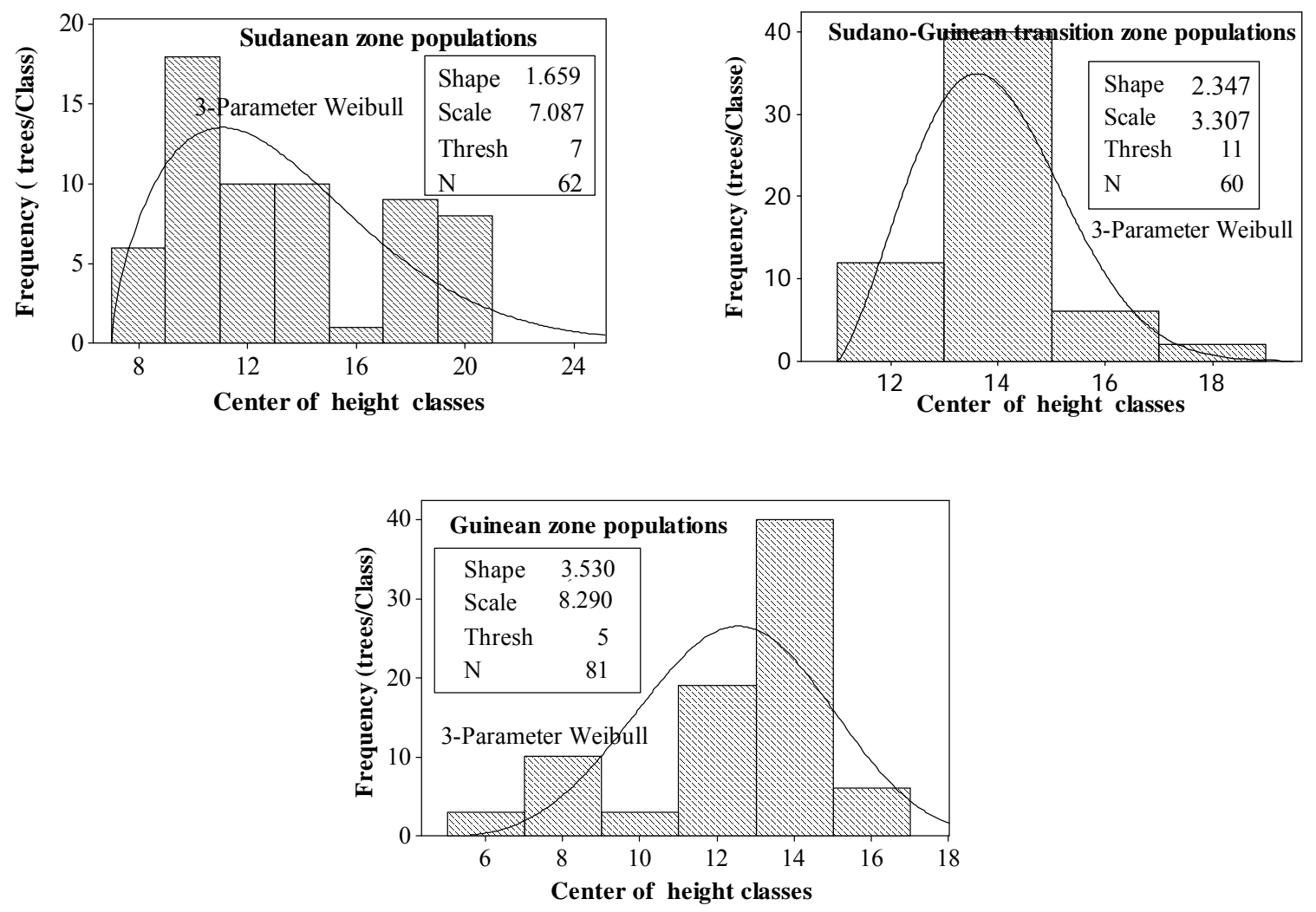

Figure 3. Total height classes distribution of trees of African fan palm populations. 
Table 3. Trees number per stand and per ecological zones of the studied B. aethiopum populations.

\begin{tabular}{|c|c|c|c|c|c|}
\hline Ecological zones & B. aethiopum populations & Sampled area $\left(\mathrm{m}^{2}\right)$ & $\begin{array}{l}\text { Number of } \\
\text { trees }\end{array}$ & $\begin{array}{l}\text { Number of trees } \\
\text { per ha }\end{array}$ & $\begin{array}{c}\text { Number of trees per } \\
\text { ecological zones (trees } / \text { ha) }\end{array}$ \\
\hline \multirow{4}{*}{ Sudanian zone } & Goroubi & 1000 & 3 & 30 & \multirow{4}{*}{155} \\
\hline & Lombou-loumbou & 1000 & 21 & 210 & \\
\hline & Niaro & 1000 & 21 & 210 & \\
\hline & Kongourou & 1000 & 17 & 170 & \\
\hline \multirow{2}{*}{$\begin{array}{l}\text { Sudano-Guinean } \\
\text { Transition zone }\end{array}$} & Akomiah & 2000 & 30 & 150 & \multirow{2}{*}{150} \\
\hline & Ouorghi & 2000 & 30 & 150 & \\
\hline \multirow{4}{*}{ Guinean zone } & $\mathrm{Se}$ & 1000 & 20 & 200 & \multirow{4}{*}{162} \\
\hline & Pahou & 1000 & 18 & 180 & \\
\hline & Grand Popo & 2000 & 22 & 110 & \\
\hline & Ouidah & 1000 & 21 & 210 & \\
\hline \multicolumn{2}{|r|}{ Total } & 13,000 & 203 & - & - \\
\hline
\end{tabular}

lations. The average number of trees of African fan palm was 156 trees per hectare across the study area. The density varies from 150 trees per hectare with stands of Sudano-Guinean Transition zone to 162 trees/ha when considering populations of Guinean zone. The lower number of trees /ha were recorded in populations of Goroubi (30 trees/ha); Grand-Popo (110 trees/ha), Ouorghi and Akomiah (150 trees/ha). Table 4 showed the structural characteristics and fruit production of African Fan Palm trees. The mean diameter at breast high of the palm trees ranged from $25.56 \mathrm{~cm}$ (Population of Se) to $62.03 \mathrm{~cm}$ (Population of Niaro) and Kongourou $(62.05 \mathrm{~cm})$. For the populations of Ouorghi, Akomiah, Goroubi, Grand Popo and Loumbou-loumbou, the mean diameter was respectively $31.55 \mathrm{~cm} ; 33.92 \mathrm{~cm} ; 34.43 \mathrm{~cm} ; 33.88 \mathrm{~cm}$ and $36.32 \mathrm{~cm}$. When considering the populations of Ouidah and Pahou, the mean diameter of the fan palm trees was as follows: $42.99 \mathrm{~cm}$ and $39.1 \mathrm{~cm}$. There is a highly significant difference within and between the trees populations as far as the trees diameter is concerned $(P<$ 0.001). When considering the ecological zones, the mean tree diameter was $52.20 \mathrm{~cm}$ with the Sudanian populations; $32.73 \mathrm{~cm}$ in the Sudano-Guinean Transition zone and $35.34 \mathrm{~cm}$ in the Guinean zone. The mean diameter of the African fan palm trees highly varied according to the ecological zones.

The mean total height of the trees varied from $9.77 \mathrm{~m}$ (Population of Kongourou) to $17.52 \mathrm{~m}$ (Population of Loumbou-loumbou). When considering the population of Akomiah, Goroubi, Ouidah and Ouorghi, the mean total height of the trees was respectively $13.98 \mathrm{~m} ; 13.50 \mathrm{~m}$; $12.79 \mathrm{~m}$ and $13.96 \mathrm{~m}$. There is a highly significant difference between the African fan palm trees populations as far as the trees total height is concerned $(P<0.001)$. When considering the ecological zones, the mean total height of trees varies from $12.38 \mathrm{~m}$ (populations of Gui- nean zone to $13.16 \mathrm{~m}$ (Populations of Sudanian zone) and $13.97 \mathrm{~m}$ (Population of Sudano-Guinean Transition zone).

\subsection{Fruits Production of B. aethiopum Populations}

The fruit number increased with size as shown on Figure 4. The minimum fruiting diameter was $25 \mathrm{~cm}$ with a maximum of $85 \mathrm{~cm}$. The maximum average number of fruit per tree $(120-140 \mathrm{~cm})$ was obtained for the diameter class centre $55 \mathrm{~cm}$ while in the younger diameter class $(25-45 \mathrm{~cm})$ this average number ranged from 60 to 80 . Table 3 also showed fruit production feature of African fan palm populations. The average number of fruit per tree started to decrease from diameter class centre $85 \mathrm{~cm}$. The average number of fruits bunch varied from 3 (Population of Grand-Popo) to 10 (Population of Loumbou-loumbou). For the populations of Niaro, Ouidah, Ouorghi, Kongourou, the average number of fruit bunch was respectively: $7.4 ; 7.83 ; 7.47$ and 8.2 . There is a significant difference between the African fan palm populations as far as the number of fruit bunch per tree is concerned. When considering the ecological zones, the average number of fruit bunch was 8.65 for the populations of the Sudanian zone; 6.12 in the SudanoGuinean Transition zone and 7.21 for the populations of Guinean zone.

The average number of fruit per tree varied from 14.5 (Population of Grand Popo) to 103.4 (Population of Pahou). When considering the populations of Loumbouloumbou, Niaro, Ouidah, Ouorghi and Kongourou, the average number of fruit per tree was respectively: 50.77 ; 86; 91.17; 89.74: 89.20. When considering the different ecological zones, the average number of fruit per tree was 62.58 for Sudanian zone populations; 77.48 for populations of Sudano-Guinean Transition zone and 85.41 
Table 4. Structural characteristics and fruit production of African fan palm trees. Means with the same letter are not statistically different according to Turkey homogeneity test.

\begin{tabular}{|c|c|c|c|c|c|c|c|}
\hline $\begin{array}{l}\text { B. aethiopum } \\
\text { populations }\end{array}$ & $\begin{array}{c}\text { Mean } \\
\text { DBH }(\mathbf{c m})\end{array}$ & $\begin{array}{l}\text { Mean total } \\
\text { height (m) }\end{array}$ & $\begin{array}{l}\text { Average number of } \\
\text { bunch of fruit per tree }\end{array}$ & $\begin{array}{l}\text { Average number } \\
\text { of fruit per tree }\end{array}$ & $\begin{array}{l}\text { Average number } \\
\text { of seeds per fruit }\end{array}$ & $\begin{array}{l}\text { Fruit } \\
\text { length }\end{array}$ & $\begin{array}{l}\text { Fruit } \\
\text { width }\end{array}$ \\
\hline Akomiah & $33.92 \mathrm{ab}$ & $13.98 \mathrm{c}$ & $6.12 \mathrm{ab}$ & $77.48 \mathrm{ab}$ & $2.50 \mathrm{a}$ & $12.95 \mathrm{a}$ & $14.98 \mathrm{a}$ \\
\hline Goroubi & $34.43 \mathrm{ab}$ & $13.50 \mathrm{bc}$ & $7 \mathrm{ab}$ & $35.67 \mathrm{ab}$ & $2.75 \mathrm{a}$ & $13.23 \mathrm{a}$ & $12.87 \mathrm{a}$ \\
\hline Granp Popo & $33.88 \mathrm{ab}$ & $9.92 \mathrm{a}$ & $3 a$ & $14.50 \mathrm{a}$ & - & - & - \\
\hline Loumbou-lombou & $36.32 \mathrm{bc}$ & $17.52 \mathrm{~d}$ & $10 \mathrm{~b}$ & $50.77 \mathrm{ab}$ & $1.69 \mathrm{a}$ & $13.29 \mathrm{a}$ & $14.26 \mathrm{a}$ \\
\hline Niaro & $62.63 \mathrm{~d}$ & $11.50 \mathrm{ab}$ & 7.40ab & $86.00 \mathrm{ab}$ & $2.11 \mathrm{a}$ & $12.42 \mathrm{a}$ & $13.56 \mathrm{a}$ \\
\hline Ouidah & $42.99 \mathrm{c}$ & $12.79 b c$ & $7.83 \mathrm{ab}$ & $91.17 \mathrm{ab}$ & - & - & - \\
\hline Ouorghi & $31.55 \mathrm{ab}$ & $13.96 \mathrm{c}$ & $7.47 \mathrm{ab}$ & $89.74 \mathrm{ab}$ & $2.54 \mathrm{a}$ & $13.39 \mathrm{a}$ & $14.16 \mathrm{a}$ \\
\hline Pahou & $39.1 \mathrm{bc}$ & $13.38 \mathrm{bc}$ & $7.7 \mathrm{ab}$ & $103.40 \mathrm{~b}$ & - & - & - \\
\hline Sè & $25.56 \mathrm{a}$ & $13.77 \mathrm{c}$ & $5.8 \mathrm{ab}$ & $64.6 \mathrm{ab}$ & $2.67 \mathrm{a}$ & $12.47 \mathrm{a}$ & $14.53 \mathrm{a}$ \\
\hline Kongourou & $62.05 \mathrm{~d}$ & $9.77 \mathrm{a}$ & $8.20 \mathrm{ab}$ & $89.20 \mathrm{ab}$ & $2.00 \mathrm{a}$ & $14.30 \mathrm{a}$ & $14.70 \mathrm{a}$ \\
\hline Probability (\%) & 0.000 & 0.000 & 0.030 & 0.020 & 0.155 & 0.939 & 0.557 \\
\hline \multicolumn{8}{|l|}{ Ecological zones } \\
\hline Sudanian & $52.20 \mathrm{~b}$ & $13.16 \mathrm{ab}$ & $8.65 b$ & $62.58 \mathrm{a}$ & $2 \mathrm{a}$ & $13.03 \mathrm{a}$ & $13.84 \mathrm{a}$ \\
\hline $\begin{array}{l}\text { Sudano-Guinean } \\
\text { Transition }\end{array}$ & $32.73 \mathrm{a}$ & $13.97 \mathrm{~b}$ & $6.12 \mathrm{a}$ & $77.48 \mathrm{a}$ & $2.67 \mathrm{a}$ & $12.47 \mathrm{a}$ & $14.53 \mathrm{a}$ \\
\hline Guinean & $35.34 \mathrm{a}$ & $12.38 \mathrm{a}$ & $7.21 \mathrm{ab}$ & $85.41 \mathrm{a}$ & $2.52 \mathrm{a}$ & $13.20 \mathrm{a}$ & $14.52 \mathrm{a}$ \\
\hline Probability (\%) & 0.000 & 0.003 & 0.023 & 0.092 & 0.089 & 0.851 & 0.415 \\
\hline
\end{tabular}

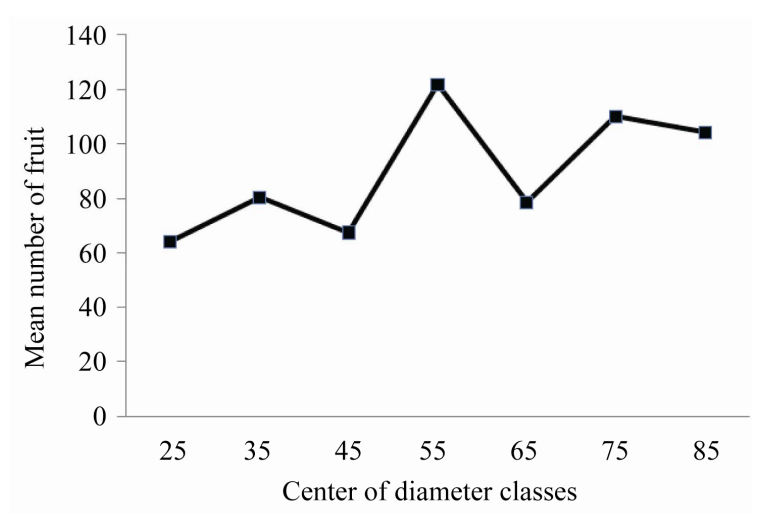

Figure 4. Diameter class distribution of number of fruits per African fan palm tree.

for populations of Guinean zone. The mean length of the fruits varied from $12 \mathrm{~cm}$ (Populations of Niaro, Se) to 14.3 (Population of Kongourou) while the mean width of the fruit varied from $12 \mathrm{~cm}$ (Population of Goroubi) to $14.98 \mathrm{~cm}$ (Population of Akomiah).

\subsection{Correlations between Fruit Production Parameters}

Table 5 showed the correlation patterns between trees $\mathrm{dbh}$, the fruit number and the number of fruit bunch per tree. The number of fruit bunch and the number of fruits per tree were not correlated with the diameter at breast height. However, the number of fruit per tree was strongly correlated with the number of fruit bunch it bears. There was strong correlation between fruit size (length and width) and the number of seeds per fruit (Table 6). Table 7 showed the number of seed per fruit according to populations and ecological zones. When considering the ecological zones, fruits in populations of the Sudanian zone (Goroubi, Loumbou-loumbou, Niaro) and in SudanoGuinean transition zone (Akomiah, Ouorghi) have three seeds while those of Guinean zone have one or two seeds. The average fruit number per female tree varies between the populations within a given ecological zone but not from one ecological zone to the other. African fan palm trees in the Sudanian populations were larger (high mean dbh, high total height and high number of fruit cluster) but did not have the higher number of fruits per tree. Trees in the Ouidah population produced the highest number of fruit (91.17 fruit per tree in average). Tees in the Guinean zone produced the highest number of fruits with an average of 85.4 fruits per tree. Most of the palm trees in the Sudano-Guinean transition zone were female while those in the Sudanian zone were almost equal in sex (Table 8).

\section{Discussion}

\subsection{Structural Characteristics of B. aethiopum Populations}

The mean number of palm trees per hectare recorded in 
Table 5. Correlation between trees dbh, fruit number and number of fruit bunch per trees.

\begin{tabular}{cccc}
\hline & Number of fruit bunch & Fruit number & Dbh \\
\hline Number of fruit bunch & 1 & & \\
Fruit number & $0.707^{* * *}$ & 1 & \\
Dbh & 0.157 & 0.159 & 1 \\
\hline
\end{tabular}

Table 6. Correlation between fruit length and width and the number of seeds per fruit.

\begin{tabular}{cccc}
\hline & Fruit length & Fruit width & Seeds number \\
\hline Fruit length & 1 & & \\
Fruit width & $0.825^{* * *}$ & 1 & \\
Seed number & $0.677^{* * *}$ & $0.568^{* * *}$ & 1 \\
*** Significant Correlation at the level of $1 \%$. &
\end{tabular}

Table 7. Number of seed per fruit according to B. aethiopum populations and ecological zones.

\begin{tabular}{cccccc}
\hline \multirow{2}{*}{ B. aethiopum populations } & \multicolumn{5}{c}{ Fruits number with: } \\
\cline { 3 - 6 } & Goroubi & 1 & 0 & 2 & 1 \\
\multirow{4}{*}{ Sudanian } & Loumbou-loumbou & 5 & 4 & 3 & 0 \\
& Niaro & 3 & 2 & 4 & 0 \\
Sudano & Kongourou & 0 & 1 & 0 & 0 \\
-Guinean & Akomiah & 2 & 1 & 7 & 0 \\
Transition & Ouorghi & 1 & 4 & 8 & 0 \\
& Ouidah & - & - & - & - \\
Guinean & Se & 0 & 1 & 2 & 0 \\
& Pahou & - & - & - & - \\
\multirow{2}{*}{ Total } & Grand popo & - & - & - & - \\
\hline
\end{tabular}

Table 8. Sex ratio of trees of $B$. aethiopum populations. Means with the same letter are not statistically significant according to Student $t$ test at the level of $5 \%$.

\begin{tabular}{ccccc}
\hline Ecological zones & $\begin{array}{c}\text { B. aethiopum } \\
\text { populations }\end{array}$ & $\begin{array}{c}\text { Male trees } \\
\text { number }\end{array}$ & $\begin{array}{c}\text { Female trees } \\
\text { number }\end{array}$ & $\begin{array}{c}\text { Ratio } \\
\text { male/female }\end{array}$ \\
& Goroubi & 0 & 3 & - \\
Sudanian & $\begin{array}{c}\text { Loumbou- } \\
\text { loumbou }\end{array}$ & 8 & 13 & $0.61 \mathrm{a}$ \\
& Niaro & 11 & 10 & $1.1 \mathrm{a}$ \\
& Kongourou & 12 & 5 & $2.4 \mathrm{a}$ \\
Sudano-Guinean & Akomiah & 5 & 25 & $0.2 \mathrm{a}$ \\
Transition & Ouorghi & 8 & 22 & $0.36 \mathrm{a}$ \\
& Ouidah & 9 & 12 & $0.75 \mathrm{a}$ \\
& Se & 9 & 11 & $0.81 \mathrm{a}$ \\
Guinean & Pahou & 8 & 10 & $0.8 \mathrm{a}$ \\
& Grand popo & 12 & 10 & $1.2 \mathrm{a}$ \\
& & 82 & 121 & - \\
\hline
\end{tabular}

the different ecological zones is similar to those obtained by [24] in Wolokonto village in Burkina-Faso. The diameter at breast high for the palm trees in the Sudanian zone was higher than those of trees in Guinean and Sudano-Guinean transition zone. According to [25], Sudanian climate was suitable for the optimal development of the African fan palm trees. However, there is generally a relationship between species temperament and their stem diameter class distribution. The shade tolerant species have an all-age population structure which gives the characteristic inverse $\mathrm{J}$-shaped curve or negative exponential stems distribution. These species are stable species as far as the equilibrium stand distribution is concerned [26-31]. The bell-shaped distribution species are generally light demanding species. They are generally gap depending for their regeneration. Mortality is higher in earlier stage under closed forest canopy. The number of large trees is higher. More caution is required as far as species temperament and stem class distribution are concerned. The stem diameter distribution of species greatly varies with observed plot size. Some species having a bell-shaped distribution within small plot could show inverse J- shaped when plots are larger (regular distribution to aggregative, [32]. In Ghana, for instance, [33] showed that on a national level, the majority of the forest species have sufficient natural regeneration and most species show inverse J-shaped curves.

Furthermore, finding patterns among life histories is a challenge for modern ecology [34]. It requires linking evolution and demography and has led to many theoretical models and field studies [35]. According to [23], the use of Weibull distribution probability density function is becoming increasingly popular for modeling the diameter distributions of both even and uneven-aged forest stands. The popularity of Weibull is derived from its flexibility to take on a number of different shapes corresponding to many different observed unimodal treediameter distributions. In addition, the cumulative distribution function of Weibull exists in closed form and thus allows for quick and easy estimation of the number of trees by diameter class without integration of the probability density function once the parameters have been fitted. The bell shaped function obtained with the diameter or height classes distribution of the palm trees with a left dissymmetry corroborate the results of [36] with the African fan palm population of Wolokonto in BurkinaFaso. Similar results were also obtained by [37] with the Shea butter trees of Donfelgou in Togo. Also [23] obtained the same distribution as far as Afzelia africana trees populations are concerned in Benin. However this structure might not be derived only from the species temperament but also from human pressure. 


\subsection{Fruit and Hypocotyls Production and Sustainable Management of the B. aethiopum Populations}

Even though, the average number of fruit per tree did not vary significantly from one ecological zone to the other, trees in the Guinean zone and mainly the population of Pahou were more productive in term of number of fruit (103.4 fruits per tree). The palm tree with the higher number of fruits was from Pahou population (270 fruits). According to [16], [38] in [39], this number is higher than those obtained with the populations of African fan palm in Niger (250 fruits per tree) and in Côte d'Ivoire (50 - 100 fruits per tree).

When we considered the number of seeds per fruit, trees of populations of the Sudano-Guinean transition zone have in majority (15 out of 23 ) three seeds. The number of fruit with three seeds is higher in the populations of Sudano-Guinean Transition zone than other populations indicating that seeds from Sudano-Guinean Transition zone are suitable for hypocotyls production.

B. aethiopum tree is nowadays subjected to high pressure and this situation was emphasized by [13] who classified the species as an endangered species on which many conservation actions should be focused. This pressure on the species is related to severe fruits and hypocotyls harvesting that hypothesised natural regeneration of the species.

As each organ of the tree is of great importance, long term management of $B$. aethiopum populations is needed to improve local population livelihood. Therefore, sustainable management of African fan palm populations for providing woods for housing, fencing and fuel woods should mainly rely on the male trees with a sex ratio of three females for one male and an optimal number of 100 trees per hectare. On this basis, we suggested that the number of trees to be harvested should be:

- 3 males from the population of Loumbou-loumbou, 7 from Niaro and 9 from Kongourou population as far as the Sudanian zone is concerned;

- 10 and 2 female trees from Akomiah and Ouorghi populations respectively as far as the Sudano-Guinean transition zone is concerned;

- 5 male trees from each Ouidah, Sè and Pahou populations in the Guinean zone.

Natural regeneration of the palm trees should be promoted as well as hypocotyls production from nursery seed germination.

\section{Conclusions}

Ecological structure of the African fan palm populations of Benin, adjusted to Weibull distribution showed a bell shaped curve with a left dissymmetry proving the pre- dominance of young trees within these populations. Structural characteristics of the stands greatly varied from one population to the other and from one ecological zone to the other. The trees mean dbh varied from $25.56 \mathrm{~cm}$ to $62.63 \mathrm{~cm}$ while the total height of the trees from $9.77 \mathrm{~m}$ to $17.52 \mathrm{~m}$. The average number of fruit clusters varied from 3 (Population of Grand Popo) to 10 (Population of Loumbou-loumbou). The average number of fruits per tree varied from 14.5 (Population of Grand Popo) to 103.4 (Population of Pahou). The average number of seeds per fruit varied from 1 to 3 . Most of fruits from populations of Sudanean and Sudano-Guinean Transition zones had 3 seeds per fruit. The mean length of the fruits varied from $12.42 \mathrm{~cm}$ (Population of Niaro) to 14.3 $\mathrm{cm}$ (Population of Kongourou). The fruit mean width varied from $12.87 \mathrm{~cm}$ (Population of Goroubi) to 14.98 $\mathrm{cm}$ (Population of Akomiah). Environmental factors (Rainfall and temperature) seemed to discriminate the African fan palm populations of Benin and were key factors for the fruit production. When considering the ecological zones, trees of Guinean zone were higher fruit producers with an average fruits per tree of 85.4. Most of the fan palm trees of the Sudano-Guinean transition zone were female while those of the Sudanean zone were almost equal in sex. Therefore sustainable management of African fan palm populations for providing woods for housing, fencing, and fuel woods should mainly rely on the male trees with a sex ratio of 3 females for 1 male and an optimal number per hectare of 100 .

However, as the species has particularly important socio-economic value for local people, there is a priority need to address the impact of its organs' exploitation and eventually human-caused habitat fragmentation on its genetic structure for conservation purposes."

\section{REFERENCES}

[1] B. C. Pamard, "Contraintes Ecologiques et Réalités SocioEconomiques. Exemple de Tafissou, Communauté Rurale du Contact Forêt-Savane sur la Branche Ouest du 'V Baoulé' (Côte D’Ivoire)," Cahiers ORSTOM, Série Sciences Humaines, Vol. 15, No. 2, 1978, pp. 51-79.

[2] O. Bassir, "Some Nigerian Wines," West Africa Journal of Biological and Applied Chemestry, Vol. 10, 1968, pp. 42-45.

[3] N. Sokpon, E. Houankoun, C. Ouinsavi and J. Yabi, "Importance Socio-Economique du Rônier (Borassus aethiopum Mart): Différent Usages et Commercialisation de Quelques Sous Produit au Bénin," Communication PrésenTée à L'atelier Scientifique Sud-Centre, Abomey-Calavi, 2004.

[4] D. S. E. Houankoun, "Importance Socio-Economique du Rônier (Borassus aethiopum): Différents Usages et Commercialisation de Quelques Sous-Produits au Bénin," Mémoire de DEA.FLASH/UAC, 2004, p. 90. 
[5] J. Sakandé, O. G. Nacoulma, J. B. Nikiema, M. Compo, E. Bassene and I. P. Guissou, "Effect of Male Inflorescence of Borassusaethiopum," Médécine d'Afrique Noire, Vol. 51, No. 5, 2004, pp. 280-282.

[6] L. Price and B. O. Gaoh, "Local Communities and Management of the Palmyra Plantations of Dallol Naonis and the Niger River: The Example of a Dynamic of Sustainable Development in Niger," Rapport, 1998.

[7] S. Atta, "The Palmyra (Borassusaethiopum). Flowering, Biomass and Contribution of Nutrients," Rapport, UICN/ PAIGLR/MH/E, Niger, 1997, p. 24.

[8] E. Adjanohoun, V. Adjakidjè, M. A. Ahyi, et al., "Contribution Aux Etudes Ethnobotaniques et Floristiques en République Du Bénin," Agence de Coopâeration Culturelle et Technique, Niamey, 1989, p. 895.

[9] N. Sokpon, "Tenure Foncière et Propriété des Ligneux Dans Les Systèmes Agroforestiers Traditionnels au Bénin," Annales de la Faculté des Sciences de Kisangani, Numéro Spécial, 1994, pp. 115-122.

[10] N. Sokpon and J. Lejoly, "Les Plantes à Fruits Comestibles D'une Forêt Semi-Caducifoliée de Pobè au Sudest du Bénin," In: C. M. Hladik, A. Hladik, H. Pagezy, O. F. Linares and A. Froment, Eds., L'alimentation en Forêt Tropicale: Interactions Bioculturelles et Perspectives de Développement, Vol. 1, UNESCO, Paris, 1996, pp. 115124.

[11] C. Ouinsavi and N. Sokpon, "Traditional Agroforestry Systems as Tools for Conservation of Genetic Ressources of Milicia excelsa Welw. C.C. Berg. in Benin," Agroforestry Systems, Vol. 74, 2008, pp. 17-26. doi:10.1007/s10457-008-9109-6

[12] G. Agbahungba, N. Sokpon and O. et Gaoué, "State of Forest Genetic Resources of Benin," Sub-Regional Workshop FAO/IPGRI/ICRAF on the Conservation, Management, Use and Enhancement of Forest Genetic Resources in the Sahelian Zone, Ouagadougou, 22-24 September 1998, p. 30.

[13] N. Sokpon and V. Agbo, "Sacred Groves as Tools for Indigenous Forests Management in Benin," Annales des Sciences Agronomiques du Bénin, Vol. 2, 1999, pp. 161175.

[14] C. Ouinsavi, N. Sokpon and S. O. Bada, "Utilization and Traditional Strategies of in Situ Conservation of Iroko (Milicia excelsa Welw. C.C. Berg.) in Benin," Forest Ecology and Management, Vol. 207, No. 3, 2005, pp. 341-350. doi:10.1016/j.foreco.2004.10.069

[15] R. Vuattoux, "Le Peuplement de Palmier Rônier (Borassus aethiopum) D'une Savane de Côte D'Ivoire. Annales de l'Université D'Abidjan," Série E. Université d'Abidjan, Abidjan, 1968.

[16] N. W. Uhl and J. Dransfield, "Genera Palmarum," Allen Press, Lawrence, 1987.

[17] F. White, "The Vegetation of Africa," UNESCO, Paris, 1983, p. 356.

[18] F. Herzog, Z. Farah, and R. Amado, "Chemical Composition and Nutritional Significance of Wines from the
Palms Elaeis guineensis and Borassus aethiopum in the V-Baoulé, Côte d'Ivoire," Tropical Science, Vol. 35, No. 1, 1995, pp. 30-39.

[19] R. Portères, "Le Palmier Rônier (Borassus aethiopum Mart.) Dans la Province du Baoulé (Côte D'Ivoire)," Journal D'Agriculture Tropicale et de Botanique Appliquée, Vol. 11, 1964, pp. 499-514.

[20] P. B. Tomlinson and E. C. Jeffrey, "The Structural Biology of Palms," Clarendon Press, Oxford, 1990.

[21] R. L. Bailey and T. R. Dell, "Quantifying Diameter Distributions with the Weibull Function," Journal of Forest Science, Vol. 19, No. 2, 1973, pp. 97-104.

[22] J. Rondeux, "Les Mesures des Arbres et Des Peuplements Forestiers," Presses Agronomiques de Gembloux, Gembloux, 1993, p. 521.

[23] W. Bonou, R. Glèlè-Kakaï, A. E. Assogbadjo, H. N. Fonton and B. Sinsin, "Characterization of Afzelia africana Sm. Habitat in the Lama Forest Reserve of Benin," Forest Ecology and Management, Vol. 258, No. 7, 2009, pp. 1084-1092. doi:10.1016/i.foreco.2009.05.032

[24] J. M. Boffa, "Agroforestry Parklands in Sub-Saharian Africa," Food and Agriculture Organization of the United Nations, Rome, 2000, p. 259.

[25] P. L. Giffard, "Le Palmier Rônier Borassus aethiopium," Bois et forêt des tropiques, No. 116, 1967, p. 14.

[26] B. Rollet, "L'architecture des Forêts Denses Humides Sempervirentes de Plaines," Centre Technique Forestier Tropical, Paris, 1974, p. 298.

[27] T. T. Veblen, F. M. Schlegel and R. B. Escobar, "Structure and Dynamics of Old-Growth Nothofagus Forests in the Valdivian Andes," Journal of Ecology, Vol. 68, No. 1, 1980, pp. 1-31. doi:10.2307/2259240

[28] C. J. Geldenhuys, "The Use of Diameter Distributions in Sustained-Use Management of Forests: Exemples from Southern Africa," In: G. D. Piearce and D. J. Gumbo, Eds., Proceedings of an International Symposium on the Ecology and Management of Indigenous Forests in Southern Africa, Victoria Falls, 27-29 July 1992, Zimbabwe Forestry Commission and SAREC, Harare, 1992, pp. 154167.

[29] N. Sokpon, "Recherche Ecologique sur la Forêt dense Semi-Décidue de Pobè au Sud-Est du Bénin: Groupements Végétaux, Structure, Régénération Naturelle et Chute de Litière," Ph.D. Thesis, Universite Libre de Bruxelles, Bruxelles, 1995, p. 350.

[30] N. Sokpon, S. H. Biaou, C. Ouinsavi and O. Hunhyet, "Bases Techniques Pour une Gestion Durable des Forêts Claires du Nord-Bénin: Rotation, Diamètre Minimal D'exploitabilité et Régénération," Bois et Forêts des Tropiques, Vol. 287, No. 1, 2006, pp. 45-57.

[31] N. Sokpon and S. H. Biaou, "The Use of Diameter Distribution in Sustained-Use Management of Remnant Forests in Benin: Case of Bassila Forest Reserve in North Benin," Ecology and Management, Vol. 161, No. 1-3, 2002, pp. 13-25. doi:10.1016/S0378-1127(01)00488-1

[32] F. Koubouana, "Les Forêts de la Vallée du Niari (Congo): 
Etudes Floristiques et Structurales," Ph.D. Thesis, University of Paris, Paris, 1993, p. 122.

[33] W. D. Hawthorne, "Ecological Profiles of Ghanaian Forest Trees," Tropical Forest Paper 29, Oxford Forestry Institute, Oxford, 1995, p. 345.

[34] M. Begon, J. L. Harper and C. R. Townsend, "Life-History Variation," Blackwell Scientific Publications, Oxford, 1990, pp. 473-509.

[35] S. C. Stearns, "The Evolution of Life Histories," Oxford University Press, Oxford, 1992.

[36] J. Cassou and D. Depomier, "In Annonce: Réunion Tripartie Sur L'agroforesterie,” Sikasso, Burkina, 1997.

[37] W. Kperkouma, B. Sinsin, K. Guelly, K. Kokou and K.
Akpagana, "Typologie et Structure des Parcs Agroforestiers Dans la Prefecture de Donfelgou," Sécheresse, Vol. 1, No. 3, 2005, p. 8.

[38] S. Barot and J. Gignoux, "Population Structure and Life Cycle of Borassus Aethiopum Mart.: Evidence of Early Senescence in Palm Tree," Biotropica, Vol. 31, No. 3, 1999, pp. 439-448. doi:10.1111/j.1744-7429.1999.tb00386.x

[39] Fao, "International Network of Tropical Trees, Participatory Management of Forest Resources, Case Study: Community Management of Ecosystems and Conservation of Biodiversity (the Case of Gaya' Palmyra Plantations)," Technical Paper, 1998, p. 72. 